\title{
Students' Perceptions in Developing Fluid Dynamic Concept Inventory (FDCI) Assessment Based on STEM Literacy to Measure Problem-Solving Skills: A Need Analysis
}

\author{
Zainal Arifinn ${ }^{1, *}$ Sukarmin Sukarmin ${ }^{2}$, Sarwanto Sarwanto ${ }^{3}$ \\ ${ }^{1}$ Master student of Physics Education, Universitas Sebelas Maret, Jl. Ir. Sutami No. 36, Surakarta, Jawa Tengah, \\ Indonesia 57126 \\ ${ }^{2}$ Department of Physics Education, Universitas Sebelas Maret, Jl. Ir. Sutami No. 36, Surakarta, Jawa Tengah, Indonesia \\ 57126 \\ ${ }^{3}$ Department of Physics Education, Universitas Sebelas Maret, Jl. Ir. Sutami No. 36, Surakarta, Jawa Tengah, Indonesia \\ 57126 \\ *Corresponding author. Email: zainalpurwodadi@student.uns.ac.id
}

\begin{abstract}
Assessment in learning is one of the important things in measuring student skills that are tailored to the abilities needed to face the challenges of the 21 st century, one of which is being able to solve various problems. This study aims to determine students' perceptions and needs for the initial study of developing a fluid dynamic concept inventory (FDCI) assessment based on STEM Literacy. Data collection through interviews and closed question questionnaires given to 15 high school students in the city of Surakarta. Data analysis used a qualitative approach with descriptive methods. The findings of this study indicate that students still have difficulty working on dynamic fluid questions because the assessment given by the teacher has no relevance to everyday life so that students feel they have to memorize a lot of formulas to solve questions. The assessment that students want is an assessment related to phenomena that occur and are applied in various technologies. Therefore, it is necessary to develop an assessment with an appropriate approach to support learning physics on dynamic fluid topics based on STEM Literacy to measure problem solving skills.
\end{abstract}

Keywords: Assessment, Dynamic fluid, Concept inventory, STEM Literacy, Problem solving skills.

\section{INTRODUCTION}

Facing the challenges of the 21 st century, the field of education plays an important role in producing human resources who have the thinking skills and are needed in the 21 st century [1]. The future challenges of modern learning require students not only to master concepts but also to develop thinking skills [2]. One of the skills that students must have is being able to solve various problems ranging from simple to complex that occur in everyday life [3]. So that better innovation is needed in the field of education to prepare it [4]. But the fact is that schools do not prepare their students to solve real-life problems, because the knowledge gained at school sometimes cannot reach this and there is a gap between learning in school and what students need while in society [5].

According to research SK Jua, Sarwanto, and Sukarmin [6] from the results of descriptive analysis the percentage of students' problem solving skills based on consecutive tests is $52.93 \%$ of various indicators. These results indicate that students' problem solving skills are included in the low category. Meanwhile, according to research by Putra et al [7], it shows that the problem solving ability of high school students in Ngawi is still in the moderate category so that efforts need to be made to improve. When students are low in solving problems, they may lack understanding of certain material being taught [2]. 
The quality of learning can be seen in terms of the process and in terms of results. The success of the learning process can be seen from the assessments made by students, so that assessment is an integral part of the learning process. Assessment is often considered as one of the three main pillars of the learning process consisting of planning, implementation, and assessment. Rate the pitch standards have played an important role in the development of teaching, curricula have, and educational space [8]. Assessment helps teachers to understand what students know and can do as do the learning, then assist teachers in understanding which aspects of the curriculum that works well for students and which are not, and this gives evidence about how well students achieve the learning objectives [9]. Conceptual understanding is the most basic things that must be owned by the students in learning physics. This is because conceptual understanding is the skill of understanding physics concepts correctly / not misconceptions, in the sense of understanding physics concepts that apply universally throughout the world [10]. Concept inventory is an assessment-based research to investigate students' understanding of certain physics concepts [11] and has played an important role in changing the way physics is taught and the curriculum used for that learning [12].

STEM literacy is very important for students about to enter the labor market, as it is a core competency of $21 \mathrm{st}$ century workers. Therefore, students must become problem solvers, innovators, technology specialists, and educated people [13]. STEM literacy is the ability of students to be able to identify, apply and integrate the concepts of Science, Technology, Engineering, and Mathematics to be able to understand complex problems by innovating solutions like experts [14]. Here it can be seen that the relationship between STEM literacy and problem solving skills cannot be separated and need each other as capital to face the modern era and is very much needed in the field of educational assessment. The problem is that teachers have such a limited understanding of what STEM is and what it means for their teaching so there seems to be difficulty in developing it. Thus organizations with expertise in assessment research and development should make appropriate assessments to measure the various learning and affective outcomes of STEM- integrated education [15]. Developing valid votes and reliable of interdisciplinary learning in STEM has been a challenge for teachers [16].

One of the physical materials related to many natural and technological phenomena is fluid mechanics. The properties that occur in fluid dynamic are very important to understand because they have many applications in everyday life, both in the form of simple technology and advanced technology [17]. The basic concepts that students need to master on the topic of fluid dynamics are the application of the concept of the continuity equation, and the Bernoulli equation [18]. Several previous studies have revealed students' difficulties in applying fluid concepts. Students' difficulties related to fluid mechanics have been revealed by A. Suarez et al. [19] revealing students' failure to integrate continuity equations and Bernoulli's law. Then according to research P. L. Y. Kristian, C. Cari, and W. Sunarno [20] showed that students lacked in understanding Bernoulli's principle and its application.

Of course, this gap cannot be blamed on one party alone because the components are interrelated, the assessment that has been developed by the teacher or researcher may still be difficult for students and may not provide space for students to respond to the assessment that has been given by the teacher. So that the assessment does not provide maximum results [21]. Previous research only looked at the problem from the teacher's perspective [22]. The existence of a needs analysis by involving students in gathering ideas and what they want from the assessment is needed further so that the assessment is meaningful for students [23].

This needs analysis aims to find problems, difficulties, and deficiencies in the instruments that have been used by teachers and students as objects in education must also be included in this analysis. This research is an early stage in developing a Fluid Dynamic Concept Inventory (FDCI) assessment based on STEM literacy to measure students' problem solving skills.

\section{METHODS}

In this study using a combination of data, it is hoped that the analysis can be as close as possible to the needs of students and interests to achieve its main goal, which is to find the needs of students in dynamic fluid assessment. This study uses a descriptive qualitative research framework that aims to find and present facts, realities, symptoms and events to be presented accurately [24]. Qualitative descriptive research is systematically recording the overall picture of a detailed topic or activity [25].

The research method used is semi-structured interviews with 15 high school students in the city of Surakarta with the main focus on finding difficulties and students' views on the assessment developed by the teacher as well as students' needs and suggestions for developing a better dynamic fluid assessment. In addition, this study also uses closed questions with questionnaires as reinforcement in this study which is used to measure students ' interest in the assessment that will be developed. In the preparatory stage, research stages are carried out and make a list of questions and select respondents to be studied. The implementation stage was carried out by interviewing 15 high school students in the city of Surakarta. Then from the results of the interviews, the results were obtained which would later be analyzed with a qualitative approach so that the research conclusions were obtained and the final stage was the writing of the report. 


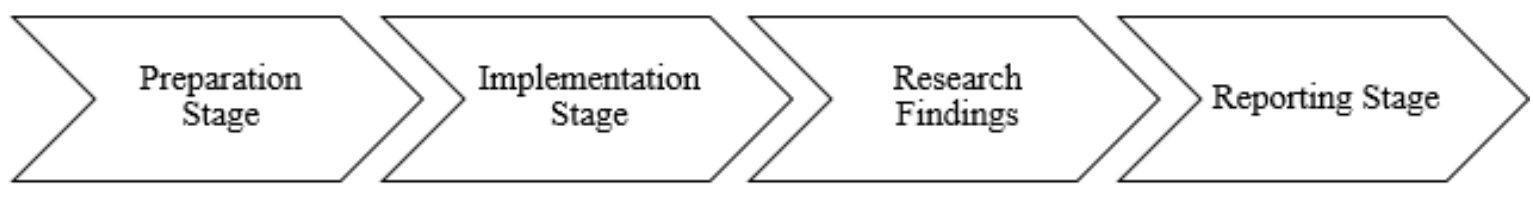

Figure 1. Research Steps

Figure 1 shows a series of research that will be carried out. At the preparatory stage, research preparation was carried out and made a list of questions and selected respondents for research. The implementation phase was carried out by

\section{RESULT AND DISCUSSIONS}

A good Concept Inventory differs from the usual valuation [26]. The opinions of the students play an important role in analyzing the extent to which interviewing 15 high school students in the city of Surakarta, then from the results of the interviews, the results obtained which would later be analyzed with a qualitative approach so that the conclusions of the study were obtained and the last stage was report writing.

students understand the material and are able to provide suggestions to the teacher as table 1 shows the needs analysis of the students.

Table 1. Needs analysis of student responses

\begin{tabular}{|c|c|c|}
\hline No. & Question & Student Response \\
\hline 1 & $\begin{array}{l}\text { Do you feel that you are still having trouble doing } \\
\text { the dynamic fluid assessment given by the teacher? }\end{array}$ & $\begin{array}{l}4 \text { students said they rarely found it difficult, while } 6 \\
\text { students felt it was often difficult and } 5 \text { students very } \\
\text { often had difficulty working on dynamic fluid } \\
\text { questions. }\end{array}$ \\
\hline 2 & $\begin{array}{l}\text { How do you think about the dynamic fluid } \\
\text { assessment given by the teacher? }\end{array}$ & $\begin{array}{l}\text { The assessments given by the teacher mostly tend to be } \\
\text { in the form of questions that lead to questions using } \\
\text { many physics equations in their solution. }\end{array}$ \\
\hline 3 & $\begin{array}{l}\text { Is the assessment / test given by the teacher in the } \\
\text { form of story questions and is it related to the } \\
\text { phenomena of everyday life? }\end{array}$ & $\begin{array}{l}\text { Most respondents said that the assessments made by the } \\
\text { teacher did not describe the relationship between } \\
\text { concepts and everyday phenomena and were more } \\
\text { likely to be mathematical questions so that students felt } \\
\text { that in solving these questions they had to use many } \\
\text { formulas given by the teacher. }\end{array}$ \\
\hline 4 & $\begin{array}{l}\text { Are you able to know the steps or strategies in } \\
\text { solving physics problems? }\end{array}$ & $\begin{array}{l}\text { Most students said that they were able to work on the } \\
\text { problems in physics if they had memorized the formula } \\
\text { given by the teacher. However, they have not seen how } \\
\text { it is applied in everyday life. }\end{array}$ \\
\hline 5 & $\begin{array}{l}\text { What do you think about the application of STEM } \\
\text { literacy when integrated with dynamic fluid tests? }\end{array}$ & $\begin{array}{l}13 \text { students said they agreed that if STEM literacy was } \\
\text { integrated with dynamic fluid assessment, they would } \\
\text { feel more interested in doing it. Meanwhile, } 2 \text { students } \\
\text { disagreed with the existence of STEM literacy in } \\
\text { learning because they felt it was too complicated }\end{array}$ \\
\hline 6 & $\begin{array}{l}\text { What are your suggestions for developing dynamic } \\
\text { fluid assessments so that they can be useful in your } \\
\text { learning and make you understand the concept of } \\
\text { dynamic fluids? }\end{array}$ & $\begin{array}{l}\text { The majority of students said that dynamic fluid } \\
\text { assessment should be related to the phenomena that } \\
\text { occur around them. In addition, they want physics } \\
\text { assessments not to memorize lots of formulas. Then in } \\
\text { the assessment, there is new knowledge that they can } \\
\text { and are able to invite them to think broadly. }\end{array}$ \\
\hline
\end{tabular}

The first question shows that there are differences in perceptions about the assessment given by the teacher where most students still often have difficulty working on questions and some students rarely experience difficulties. This happened according to students because the questions given by the teacher used a lot of questions that required students to memorize physics equations to solve problems. This is in line with research by $\mathrm{R}$. 
Azizah, L. Yuliati, and E. Latifah [27] that $76 \%$ of students have difficulty solving problems on the question by reason of forgetting or not understanding, $19 \%$ of students do not understand the solution to the problem. , and only $5 \%$ of students were able to solve the problems in the questions. In addition, these difficulties occur because in learning the delivery of material has not been conveyed properly and students receive the material partially [28].

In the next question, according to the students, the questions given by the teacher were not related to the phenomena that occurred around the students so that they felt that there was no relevance between what they experienced at home and the material that students received at school. The conception of students at the level of secondary education or higher appears as a mixture of spontaneous ideas generated by their daily life experiences in the real world [29]. This happens because students have a tendency that the physics material they study in school is solely for the purpose of completing physics on school tests and exams without realizing the relevance of these concepts in their daily lives [30].

Fluid dynamic material is very important to be studied and understood by students because it is closely related to various engineering technologies, but in learning this material, it still uses many formula derivations, resulting in students having difficulty learning the concepts. Poor mastery of concepts can cause students to not be able to understand physics material well [31]. Based on the research of O. Saputra et al., $65.32 \%$ of students' understanding of dynamic fluid materials had misconceptions, $13.06 \%$ of students did not understand, $6.76 \%$ of students were lucky/less confident and $14.86 \%$ had scientific knowledge about fluid concepts. dynamic [32].

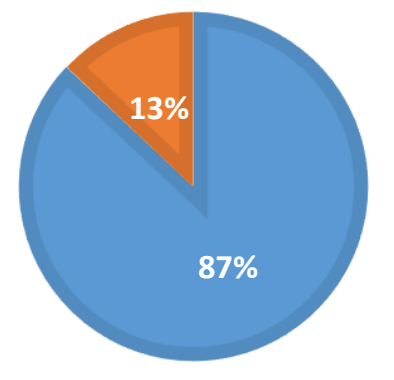

minterested not interested

Figure 2. Student interest in assessment development

The majority of students are interested in the development of this assessment, although there are 2 students who are not interested in the assessment, students who are interested in the reason that fluid dynamic assessment when associated with various technological phenomena is very interesting to do. Students' interest in developing this instrument can be seen in Figure 2. A total of 13 students were interested in developing a STEM literacy-based Fluid Dynamic Concept Inventory (FDCI) assessment to measure problem solving skills while 2 students were not interested in this development.

Suggestions from students in developing this assessment are in the preparation of which there is more understanding of concepts and their application in engineering technology and reducing the use of memorizing formulas in problem solving. Furthermore, students' expectations from the assessment that will be developed are not only with the aim of getting good grades but also to measure broader thinking skills and not being confined in mathematical formulas. This is in accordance with the statement of M. F. Lee, et al [33] that most of the world of work does not only focus on academic achievement as the main selection criteria, but also emphasizes the soft skills of graduates as criteria for work. Having excellent academic achievements does not guarantee employment for graduates due to high competition in the job market.

\section{CONCLUSION}

From the various opinions of the students above, it can provide information that there are still many students who often have difficulty finishing on fluid dynamic questions given by the teacher. This happens because students do not understand the concept of material, and the assessment given by the teacher requires a lot of formulas or equations that must be memorized by students in answering them. In addition, the assessment given by the teacher is not fully related to the phenomenon or its application in various technologies. Suggestions from the students from the results of this interview were that they wanted an assessment that would encourage students to think broadly and not be fixated by the derivation of many formulas. There is a dynamic fluid assessment innovation based on STEM literacy, students are very interested in trying this assessment to measure their problem solving thinking skills. 


\section{REFERENCES}

[1] S. Kim and E. Seidman, "Improving 21st-century teaching skills: The key to effective 21 st- century learners," Res. Comp. Educ., vol. 2, no. 3, pp. 1-19, 2019. DOI : $10.1177 / 1745499919829214$

[2] J. R. Batlolona, C. Baskar, M. A. Kurnaz, and M. Leasa, "The Improvement of Problem-Solving Skills and Physics Concept Mastery on Temperature And Heat Topic," J. Pendidik. IPA Indones., vol. 7, no. 3, pp. 273-279, 2018.

[3] S. Saragih, S. Nisa, and Zulkarnain, "The Impact of Learning Model Based on 2013 Curriculum Towards Contextual Problem Solving Skill," Conf. MSCEIS 2019, Oct. 12, Bandung, Indones., pp. 17, 2020.

[4] Y. S. Hsu, "Opportunities and challenges of STEM education," Asia-Pacific STEM Teaching Practices: From Theoretical Frameworks to Practices. pp. 1-16, 2019.

[5] N. Y. Rustaman, "Assessment in Science Education," in International Conference on Mathematics and Science Education, ICMScE 2017, 2017, vol. 895, no. 1.

[6] S. K. Jua, Sarwanto, and Sukarmin, "The Profile of Students ' Problem-Solving Skill in Physics Across Interest Program in the Secondary School," J. Phys. Conf. Ser. ICoSMEE, 2018.

[7] A. A. I. A. Putra, N. S. Aminah, A. Marjuki, and Z. S. Pamungkas, "The profile of student's problem solving skill using analytical problem solving test (apst) on the topic of thermodynamic," J. Phys. Conf. Ser., vol. 1567, 2020.

[8] J. T. Laverty and M. D. Caballero, "Analysis of the Most Common Concept Inventories in Physics : What are We Assessing?," Phys. Rev. Phys. Educ. Res., vol. 14, no. 1, p. 10123, 2018. DOI : 10.1103/PhysRevPhysEducRes.14.010123

[9] National Research Council, STEM Integration in $K$ 12 Education: Status, Prospects, and an Agenda for Research. Washington, DC: The National Academies Press, 2014.

[10] H. Putranta and Supahar, "Development of PhysicsTier Tests ( PysTT) to Measure Students ' Conceptual Understanding and Creative Thinking Skills: A Qualitative Synthesis," J. Educ. Gift. Young Sci., vol. 7, no. 3, pp. 747-775, 2019. DOI : $10.17478 /$ jegys. 587203

[11] A. Madsen, S. B. Mckagan, and E. C. Sayre, "Best Practices for Administering Concept Inventories," Phys. Teach., vol. 55, pp. 1-8, 2017. DOI : $10.1119 / 1.5011826$

[12] S. M. Stoen, M. A. Mcdaniel, R. F. Frey, K. M. Hynes, and M. J. Cahill, "Force Concept Inventory : More than just conceptual understanding," Phys. Rev. Phys. Educ. Res., vol. 16, no. 1, p. 10105, 2020. 10.1103/PhysRevPhysEducRes.16.010105

[13] S. Techakosit, "The Development of STEM Literacy Using the Learning Process of Scientific Imagineering through AR," Int. J. Emerg. Technol.
Learn., vol. 13, no. 1, pp. 230-238, 2018. 10.3991/ijet.v13i01.7664

[14] J. L. Docktor et al., "Assessing Student Written Problem Solutions: A Problem-Solving Rubric with Application to Introductory Physics," Phys. Rev. Phys. Educ. Res., vol. 12, pp. 1-18, 2016. 10.1103/PhysRevPhysEducRes.12.010130

[15] E. Dare, "Creating a continuum of STEM models: Exploring how K-12 science teachers conceptualize STEM education," Int. J. Sci. Educ., vol. 41, no. 12, pp. 1701-1720, 2019. 10.1080/09500693.2019.1638531

[16] X. Gao, P. Li, J. Shen, and H. Sun, "Reviewing assessment of student learning in interdisciplinary STEM education," International Journal of STEM Education, vol. 7, no. 1. 2020. 10.1186/s40594020-00225-4

[17]M. Abdullah, "Pengantar Fisika Statistik untuk Mahasiswa," 2007.

[18]T. N. Diyana, Sutopo, and Sunaryono, "The Effectiveness of Web-Based Recitation Program on Improving Students' Conceptual Understanding in Fluid Mechanics," J. Pendidik. IPA Indones., vol. 9, no. 2, pp. 219-230, 2020 10.15294/jpii.v9i2.24043

[19] A. Suarez, S. Kahan, G. Zavala, and A. C. Marti, "Students , Conceptual Difficulties in Hydrodynamics," Phys. Rev. Phys. Educ. Res., vol. 020132, pp. 1-12, 2017.

[20] P. L. Y. Kristian, C. Cari, and W. Sunarno, "The Analysis of the Mathematics Concept Comprehension of Senior High School Student on Dynamic Fluid Material," Int. Conf. Sci. Educ., 2018.

[21]J. Grant, "Learning needs assessment: Assessing the need Learning needs assessment : assessing the need," Br. Med. Journa, vol. 324, no. 7330, pp. 156-159, 2002.

[22] İ. Kozikoğlu, "Investigating Critical Thinking in Prospective Teachers: Metacognitive Skills, Problem Solving Skills and Academic SelfEfficacy," J. Soc. Stud. Educ. Res. Sos., vol. 10, no. 2, pp. 111-130, 2019.

[23] C. Crişan, O. Ghimbulu, and A. Pavelea, "A Need Assessment on Students ' Career Guidance," Procedia - Soc. Behav. Sci., vol. 180, no. November 2014, pp. 1022-1029, 2015.

[24] H. R. Widarti, D. A. Rokhim, and A. B. Syafruddin, "The development of electrolysis cell teaching material based on stem-pjbl approach assisted by learning video: A need analysis," J. Pendidik. IPA Indones., vol. 9, no. 3, pp. 309-318, 2020.

[25] K. Jayadi, A. Abduh, N. Makassar, and U. N. Makassar, "Current Changes in Digital Anthropology and Literacy in Higher Education," vol. 11, no. 1, pp. 482-489, 2020.

[26] A. Madsen et al., "topics Resource Letter RBAI-2 : Research-based assessment instruments: Beyond 
physics topics," Am. Assoc. Phys. Teach., vol. 87, no. 5, pp. 350-369, 2019.

[27]R. Azizah, L. Yuliati, and E. Latifah, "KESULITAN PEMECAHAN MASALAH FISIKA PADA SISWA SMA," J. Penelit. Fis. dan Apl., vol. 5, no. 2, pp. 44-50, 2015.

[28] P. V Engelhardt, S. Robinson, E. P. Price, P. S. Smith, and F. Goldberg, "Developing a conceptual assessment for a modular curriculum," Phys. Rev. Phys. Educ. Res., pp. 4-7, 2017.

[29] U. Besson, "Students' conceptions of fluids," Int. J. Sci. Educ., vol. 26, no. 14, pp. 37-41, 2014.

[30]H. Chu, D. F. Treagust, S. Yeo, and M. Zadnik, "Understanding of Thermal Concepts in Everyday Contexts," Int. J. Sci. Eval. Students, vol. 34, no. 10, pp. 1509-1534, 2012.
[31] N. Amin, Wiendartun, and A. Samsudin, "Analisis Intrumen Tes Diagnostik Dynamic-Fluid Conceptual Change Inventory ( DFCCI ) Bentuk Four-Tier Test pada Beberapa SMA di Bandung Raya," Pros. SNIPS 2016, no. July, 2016.

[32] O. Saputra, A. Setiawan, D. Rusdiana, and Muslim, "Identifikasi Miskonsepsi Siswa Sekolah Menengah Atas ( SMA ) pada Topik Fluida Dinamis," J. Kreat. Online, vol. 7, no. 3, pp. 22-33, 2017.

[33] M. F. Lee, S. Nooridayu, M. Sohod, and A. A. Rahman, "Exploring the Mastery Level of Critical Thinking and Problem Solving Skill among the Technical Undergraduate," J. Tech. Educ. Train., vol. 11, no. 3, pp. 9-14, 2019. 